\title{
Enkele opmerkingen over beëindiging van de arbeidsovereenkomst met een bestuurder van een rechtspersoon na ontslag: opzeggen of ontbinden?
}

\author{
C. de Groot
}

\section{Inleiding}

Wanneer een rechtspersoon een bestuurder ontslaat, zal die rechtspersoon veelal ook de arbeidsovereenkomst met de bestuurder willen beëindigen. Voor de vereniging, de naamloze vennootschap en de besloten vennootschap bevat Boek 2 BW, in samenhang met het arbeidsovereenkomstenrecht in Boek 7 BW, een regeling die ertoe leidt dat die beëindiging van de arbeidsovereenkomst met een bestuurder op eenvoudige wijze mogelijk is. Voor de stichting geldt tot nu toe een andere regeling. Hierna komt in paragraaf 2 de dubbele rechtsbetrekking tussen een bestuurder en de rechtspersoon aan de orde: die rechtsbetrekking is zowel ondernemingsrechtelijk als arbeidsrechtelijk. Paragraaf 3 gaat over beëindiging van een arbeidsovereenkomst in het algemeen. Deze twee paragrafen zijn een opmaat naar de daarop volgende paragrafen over de latere rechtspraak van de Hoge Raad over de rechtspositie van bestuurders (par. 4), en over de beëindiging van de arbeidsovereenkomst met een bestuurder (par. 5). Paragraaf 6 bespreekt nog enkele bijzonderheden rond de beëindiging van de arbeidsovereenkomst met een bestuurder. Paragraaf 7 bespreekt de afwijkende regeling bij de stichting. Daaraan zal door de voorgestelde Wet bestuur en toezicht rechtspersonen een einde komen. Dit wetsvoorstel is op 28 januari 2020 door de Tweede Kamer aanvaard, en ligt nu voor behandeling bij de Eerste Kamer. ${ }^{1}$ Het doel van het wetsvoorstel is 'de uniformering en de verduidelijking van enkele bepalingen omtrent het bestuur en de raad van commissarissen'. Paragraaf 8 is de conclusie. Daarin komt aan de orde in hoeverre het wetsvoorstel erin slaagt zijn doelstelling te verwezenlijken.

1 Kamerstukken I 2019/20, 34491, A, gewijzigd voorstel van wet, Wijziging van het Burgerlijk Wetboek in verband met de uniformering en de verduidelijking van enkele bepalingen omtrent het bestuur en de raad van commissarissen van rechtspersonen (Wet bestuur en toezicht rechtspersonen). 


\section{De Hoge Raad over bestuurders van een rechtspersoon}

In zijn uitspraak van 13 november 1992, NJ 1993/265 (A.H. Levison/MAB Groep $\mathrm{BV}$; cassatie in het belang van de wet) besliste de Hoge Raad dat een bestuurder van een rechtspersoon die een natuurlijke persoon is (een bestuurder van een rechtspersoon kan ook een andere rechtspersoon zijn) in het algemeen een arbeidsovereenkomst heeft met de rechtspersoon. ${ }^{2}$ Dit brengt mee dat het ontslag van een bestuurder van een rechtspersoon door het daartoe bevoegde orgaan betekent dat de bestuurder de bestuurstaken niet meer kan uitoefenen, en brengt ook mee dat de (resterende) arbeidsovereenkomst met de bestuurder alsnog moet worden beëindigd op de manier die het arbeidsrecht voorschrijft. De Hoge Raad overwoog in deze uitspraak over bestuurders van naamloze vennootschappen en besloten vennootschappen (hetzelfde zal gelden voor bestuurders van andere rechtspersonen zoals een vereniging en een stichting) dat:

'3.3. (...), wanneer een natuurlijk persoon als bestuurder van een naamloze of besloten vennootschap is benoemd en - zoals veelal het geval is en hier door de rechtbank is aangenomen - zijn werkzaamheden krachtens arbeidsovereenkomst verricht, een bij geldig besluit van het bevoegde orgaan van de vennootschap aan hem als bestuurder verleend ontslag wel ingevolge art. 2:134 lid 1 resp. art. 2:244 lid 1 BW meebrengt dat hij de hoedanigheid van bestuurder der vennootschap verliest en dus geen van de aan deze hoedanigheid verbonden bevoegdheden meer kan uitoefenen, maar niet tot gevolg behoeft te hebben dat ook de dienstbetrekking eindigt. Het antwoord op de vraag welke gevolgen het ontslagbesluit heeft voor de arbeidsverhouding tussen de bestuurder en de vennootschap, moet worden gegeven aan de hand van het bepaalde in de arbeidsovereenkomst en in de op arbeidsovereenkomsten toepasselijke wetsbepalingen, voor zover Boek 2 BW deze wetsbepalingen niet uitdrukkelijk terzijde stelt.'

De Hoge Raad spreekt hier over een natuurlijke persoon die bestuurder is van een naamloze vennootschap of een besloten vennootschap. Daarbij past (de uitspraak dateert uit 1992) de volgende kanttekening. Een rechtspersoon die intern toezicht wil instellen kan dat op twee manieren doen. De rechtspersoon kan een raad van commissarissen (bij een vereniging of een stichting vaak raad van toezicht genoemd) instellen. Dit is het dualistische of two tier inrichtingsmodel. De leden van de raad van de raad van commissarissen zijn veelal werkzaam op basis van een overeenkomst van opdracht. De rechtspersoon kan ook een bestuur instellen dat bestaat uit uitvoerende bestuurders en niet-uitvoerende bestuurders. Dit is het monistische of one tier inrichtingsmodel. De niet-uitvoerende bestuurders hebben een toezichthoudende taak. Ook zij zijn veelal werkzaam op basis van een overeenkomst van opdracht. Bij bestuurders van een rechtspersoon die werkzaam

2 Vgl. H. Schrama \& K. Wiersma, Ernstig verwijtbaar gedrag van bestuurders als reden voor ontslag en aansprakelijkheid, Tijdschrift voor Ontslagrecht 2019-2. 
zijn op basis van een arbeidsovereenkomst gaat het (als de rechtspersoon geen intern toezicht heeft ingesteld) om de leden van het bestuur van de rechtspersoon, en gaat het (als de rechtspersoon wel intern toezicht heeft ingesteld) om de leden van bestuur in een rechtspersoon met een dualistisch inrichtingsmodel en om de uitvoerende bestuurders in een rechtspersoon met een monistisch inrichtingsmodel.

Voor de naamloze vennootschap en de besloten vennootschap is het dualistische inrichtingsmodel opgenomen in art. 2:140 en 2:250 BW en is het monistische inrichtingsmodel op genomen in art. 2:129a en 2:239a BW. Voor de vereniging en de stichting regelt de voorgestelde Wet bestuur en toezicht rechtspersonen het dualistische inrichtbestuursmodel in art. 2:47 en 2:292a BW en het monistische bestuursmodel in art. 2:44a en 2:291a BW. ${ }^{3}$

Voor de volledigheid: art. 2:132 lid 3 BW bepaalt dat bestuurders van een naamloze vennootschap die beursgenoteerd is (aandelen of certificaten van aandelen 'zijn toegelaten tot de handel op een gereglementeerde markt of een multilaterale handelsfaciliteit') niet werkzaam zijn op basis van een arbeidsovereenkomst: bij deze bestuurders 'wordt de rechtsverhouding tussen een bestuurder en de vennootschap niet aangemerkt als arbeidsovereenkomst'. Deze bestuurders zijn werkzaam op basis van een overeenkomst van opdracht, waardoor de problematiek van beëindiging van de arbeidsovereenkomst niet speelt. Deze bepaling is het resultaat van een door de Tweede Kamer aangenomen amendement van de leden Weekers en Van Vroonhoven-Kok, ${ }^{4}$ dat als doel had te voorkomen dat een ontslagen bestuurder in een juridische procedure een (hoge) ontslagvergoeding zou kunnen afdwingen.

\section{Beëindiging van een arbeidsovereenkomst in het algemeen}

Een werkgever kan een arbeidsovereenkomst met een werknemer op verschillende manieren beëindigen. Art. 7:671a lid 1 BW gaat over opzegging. Deze bepaling houdt in dat een werkgever die voornemens is de arbeidsovereenkomst op te zeggen daarvoor toestemming moet vragen aan het Uitvoeringsinstituut werknemersverzekeringen (UWV), als de reden voor de beëindiging van de arbeidsovereenkomst is gebaseerd op art. 669 lid 3 onder a of b BW. Deze beëindigingsgronden zijn:

3 Kamerstukken II 2018/19, 34491, nr. 7 (NvW) (Wet bestuur en toezicht rechtspersonen). Vgl. onder meer S.M. Bartman, C. de Groot, J. Nijland \& I.S. Wuisman, Enkele kanttekeningen bij het wetsvoorstel bestuur en toezicht rechtspersonen, Maandblad voor Ondernemingsrecht 2016-10/11; P.J. Dortmond, Het Wetsontwerp bestuur en toezicht rechtspersonen en het verenigingsrecht, Ondernemingsrecht 2016, nr. 82; A.G.H. Klaassen, Het wetsvoorstel Wet bestuur en toezicht rechtspersonen en de semipublieke sector: een betere aansluiting op Boek 2 BW is wenselijk, Ondernemingsrecht 2017, nr. 107; J. Müller, Wet bestuur en toezicht rechtspersonen - een overzicht, Bedrijfsjuridische berichten 2016, nr. 67.

4 Kamerstukken II 2009/10, 31763, nr. 10 (amendement van de leden Weekers en Van Vroonhoven-Kok), Wijziging van boek 2 van het Burgerlijk Wetboek in verband met de aanpassing van regels over bestuur en toezicht in naamloze en besloten vennootschappen. 
a. het vervallen van arbeidsplaatsen als gevolg van de beëindiging van de werkzaamheden van de onderneming (...);

b. ziekte of gebreken van de werknemer waardoor hij niet meer in staat is de bedongen arbeid te verrichten, mits de periode, bedoeld in art. 7:670 lid 1 en $11 \mathrm{BW}$, is verstreken (...); [de bedoelde periode bedraagt twee jaar)].

Art. 7:671b lid 1 BW gaat over ontbinding. Deze bepaling houdt in dat een werkgever de kantonrechter kan verzoeken de arbeidsovereenkomst te ontbinden, als de reden voor de beëindiging van de arbeidsovereenkomst is gebaseerd op art. 7:669 lid 3 onder c tot en met i BW. Deze beëindigingsgronden zijn:

c. het bij regelmaat niet kunnen verrichten van de bedongen arbeid als gevolg van ziekte of gebreken van de werknemer met voor de bedrijfsvoering onaanvaardbare gevolgen, (...);

d. de ongeschiktheid van de werknemer tot het verrichten van de bedongen arbeid, anders dan ten gevolge van ziekte of gebreken van de werknemer, (...); e. verwijtbaar handelen of nalaten van de werknemer, zodanig dat van de werkgever in redelijkheid niet kan worden gevergd de arbeidsovereenkomst te laten voortduren;

f. het weigeren van de werknemer de bedongen arbeid te verrichten wegens een ernstig gewetensbezwaar, mits aannemelijk is dat de bedongen arbeid niet in aangepaste vorm kan worden verricht;

g. een verstoorde arbeidsverhouding, zodanig dat van de werkgever in redelijkheid niet kan worden gevergd de arbeidsovereenkomst te laten voortduren;

h. andere dan de hiervoor genoemde omstandigheden die zodanig zijn dat van de werkgever in redelijkheid niet kan worden gevergd de arbeidsovereenkomst te laten voortduren;

i. een combinatie van omstandigheden genoemd in twee of meer van de gronden, bedoeld in de onderdelen c tot en met $\mathrm{h}$, die zodanig is dat van de werkgever in redelijkheid niet kan worden gevergd de arbeidsovereenkomst te laten voortduren.

Art. 7:671a lid 1 BW en 7:671b lid 1 BW bevatten verplichte routes. Bij beëindiging van de arbeidsovereenkomst met een werknemer op grond van art. 669 lid 3 onder a of b BW moet de werkgever de arbeidsovereenkomst opzeggen, na daarvoor toestemming te hebben gekregen van het UWV. Bij beëindiging van de arbeidsovereenkomst met een werknemer op grond van art. 669 lid 3 onder $\mathrm{c}$ tot en met i BW moet de werkgever de kantonrechter verzoeken de arbeidsovereenkomst te ontbinden.

De uitspraak van de Hoge Raad in A.H. Levison/MAB Groep BV zou in beginsel meebrengen dat de rechtspersoon de arbeidsovereenkomst met de bestuurder alsnog zou moeten beëindigen via hetzij de route van opzegging, na daarvoor toestemming te hebben gekregen van het UWV, hetzij de route van ontbinding door de kantonrechter. Bij een bestuurder van een rechtspersoon zou de route voor de beëindiging van de arbeidsovereenkomst - gelet op de in art. 669 lid 3 onder c tot 
en met i BW geformuleerde beëindigingsgronden - in veel gevallen ontbinding zijn.

De Hoge Raad verwijst in A.H. Levison/MAB Groep BV naar de mogelijkheid dat Boek 2 BW het arbeidsrecht terzijde stelt. Dat doet Boek 2 BW inderdaad. Zowel voor de vereniging als voor de naamloze vennootschap en de besloten vennootschap bepaalt Boek 2 BW dat de rechter niet kan overgaan tot het uitspreken van een veroordeling tot herstel van de arbeidsovereenkomst tussen die rechtspersoon en de bestuurder (art. 2:37 lid 6 tweede volzin BW, art. 2:134 lid 3 BW en art. 2:244 lid 3 BW). Deze regeling is verklaarbaar uit het feit dat bestuurders werknemers zijn met een speciale status die meebrengt dat het daartoe bevoegde orgaan van de rechtspersoon een bestuurder 'te allen tijde' kan ontslaan (art. 2:37 lid 6 eerste volzin BW, art. 2:134 lid 1 BW en art. 2:244 lid 1 BW).

\section{Nogmaals de Hoge Raad over bestuurders van een rechtspersoon}

De Hoge Raad heeft zich in twee latere uitspraken opnieuw uitgelaten over de rechtspositie van een bestuurder van een rechtspersoon. Dit zijn de uitspraken van de Hoge Raad van 15 april 2005, NJ 2005/484 (A.W.M. Eggenhuizen/Unidek Volumebouw BV) en NJ 2005/483 (G.H.G.M. Bartelink/Ciris Creative Interactive Television BV; cassatie in het belang van de wet). ${ }^{5}$ In beide uitspraken herhaalde de Hoge Raad de overweging uit A.H. Levison/MAB Groep BV. De Hoge Raad bouwde op die uitspraak voort door de overwegen dat:

'[3.4.3/3.5.3] (...) door een ontslagbesluit ook een einde wordt gemaakt aan de arbeidsrechtelijke verhouding. Daarom heeft te gelden dat een ontslagbesluit in beginsel tevens beëindiging van de dienstbetrekking van de bestuurder tot gevolg heeft. Voor een uitzondering is slechts plaats indien een wettelijk ontslagverbod aan die beëindiging in de weg staat (...) of indien partijen anders zijn overeengekomen.'

De stelligheid waarmee deze overweging tot uitdrukking brengt dat een ontslagbesluit tevens beëindiging van de arbeidsovereenkomst tot gevolg heeft, gaat verder dan mogelijk is: het ontslagbesluit zal niet altijd mede zijn geformuleerd als een opzegging van de arbeidsovereenkomst en het ontslagbesluit is geen verzoek tot ontbinding van de arbeidsovereenkomst. In het ontslagbesluit komt dan alleen tot uiting dat de ontslagen bestuurder geen deel meer uitmaakt van het bestuur van de rechtspersoon, en dat de rechtspersoon de arbeidsovereenkomst met de bestuurder wil beëindigen. Dat laatste zal moeten gebeuren via het

5 Vgl. R.M. Beltzer \& R.D. Rietveld, 'De statutair bestuurder in de Wet werk en zekerheid', Onderneming en Financiering 2016-2; E.S. de Bock, 'Kroniek Statutair Bestuurder medio 2014 - medio 2016', ArbeidsRecht 2016, nr. 53; E.S. de Bock, 'Kroniek Statutair Bestuurder medio 2016 medio 2018', ArbeidsRecht 2018, nr. 33. 
arbeidsrecht, dat wil zeggen door middel van opzegging door de rechtspersoon, ${ }^{6}$ of door middel van ontbinding door de kantonrechter.

\section{Art. 7:671 lid 1 BW en bestuurders van een rechtspersoon}

Art. 7:671 lid 1 BW bevat een bijzonderheid. Dit artikellid bepaalt dat de werkgever de arbeidsovereenkomst met een werknemer niet eenzijdig ('zonder schriftelijke instemming van de werknemer') kan opzeggen, tenzij (onder meer):

'a. voor de opzegging toestemming is verleend als bedoeld in artikel 671a;'

of het:

'e. de opzegging een bestuurder van een rechtspersoon betreft van wie herstel van de arbeidsovereenkomst op grond van Boek 2 van het Burgerlijk Wetboek niet mogelijk is (...);.'

Op grond van art. 7:671 lid 1 onder e BW kan een werkgever de arbeidsovereenkomst altijd eenzijdig, zonder schriftelijke instemming van de werknemer, opzeggen als het gaat om de opzegging van een bestuurder van een rechtspersoon ten aanzien van wie Boek 2 BW bepaalt dat de rechter niet kan overgaan tot het uitspreken van een veroordeling tot herstel van de arbeidsovereenkomst tussen die bestuurder en de rechtspersoon. Voor een vereniging, een naamloze vennootschap en een besloten vennootschap brengt dit mee dat deze rechtspersonen de (resterende) arbeidsovereenkomst tussen die rechtspersoon en de bestuurder na ontslag altijd zonder meer kunnen beëindigen door die arbeidsovereenkomst op te zeggen. Dit komt erop neer dat die rechtspersonen na ontslag van een bestuurder door het daartoe bevoegde orgaan:

- niet alleen de (resterende) arbeidsovereenkomst met de bestuurder kunnen opzeggen op grond van art. 669 lid 3 onder a of b BW zonder toestemming te vragen aan het UWV;

- maar ook de (resterende) arbeidsovereenkomst met de bestuurder kunnen opzeggen op grond van art. 669 lid 3 onder c tot en met i BW (waarvoor toestemming van het UWV niet nodig is).

De combinatie van de aanhef van art. 7:671 lid 1 BW met onderdeel e leidt ertoe dat deze rechtspersonen die de arbeidsovereenkomst met een bestuurder willen beëindigen op grond van art. 669 lid 3 onder c tot en met i BW niet verplicht zijn de route van ontbinding van de arbeidsovereenkomst door de kantonrechter te 
volgen, maar de arbeidsovereenkomst ook op die gronden eenvoudigweg kunnen opzeggen. ${ }^{7}$

\section{Wat betekent 'de opzegging een bestuurder van een rechtspersoon (...) van wie herstel van de arbeidsovereenkomst op grond van Boek 2 van het Burgerlijk Wetboek niet mogelijk is' nog meer?}

\subsection{Art. 7:682 BW}

Art. 7:682 BW geeft de rechter de mogelijkheid de werkgever in enkele gevallen te veroordelen de arbeidsovereenkomst te herstellen, of aan de werknemer ten laste van de werkgever een billijke vergoeding toe te kennen. Een van die gevallen (art. 7:682 lid $1 \mathrm{BW}$ ) is de situatie waarin de werkgever de arbeidsovereenkomst heeft opgezegd op grond van art. 7:671a lid 1, dus gebaseerd op art. 7:669 lid 3 onder a of b BW met toestemming van het UWV. In dit geval is de werknemer van mening dat het UWV ten onrechte toestemming heeft gegeven voor de opzegging en legt de werknemer de opzegging (en eigenlijk het toestemmingbesluit) voor aan de rechter. ${ }^{8}$ Als het gaat om een bestuurder van een vereniging, een naamloze vennootschap of een besloten vennootschap, kan de rechter die rechtspersoon niet veroordelen tot herstel van de arbeidsovereenkomst tussen de rechtspersoon en de bestuurder (vanwege art. 2:37 lid 6 tweede volzin BW, art. 2:134 lid 3 BW en art. 2:244 lid 3 BW). De rechter kan aan de bestuurder wel een billijke vergoeding toekennen die de rechtspersoon moet betalen.

Voor de volledigheid: art. 7:682 lid 3 BW bepaalt in het algemeen ook dat de rechter aan een bestuurder van een vereniging, een naamloze vennootschap of een besloten vennootschap ten laste van de werkgever een billijke vergoeding kan toekennen als de opzegging in strijd is met art. 7:669 BW, dus in de situatie van opzegging van de arbeidsovereenkomst met die bestuurder die is gebaseerd op een van de beëindigingsgronden die art. 7:669 lid 3 onder a tot en met i opsomt

7 Vgl. J.H. Bennaars, De opzegging: preventief en duaal, maar dan anders, Tijdschrift Arbeidsrechtpraktijk 2014, nr. 4, met als toevoeging: 'Ook ontbinding is mogelijk, hoewel dat waarschijnlijk alleen in de rede ligt als sprake is van een opzegverbod.'; J.H. Bennaars, De bestuurder en zijn ontslag post Wwz - anything new?, Tijdschrift Arbeidsrechtpraktijk 2017, nr. 123; J.H. Bennaars, 14 jaar na de 15 april-arresten: is ontslag van een vennootschapsbestuurder echt altijd ontslag? Wat is een redelijke grond en welke (ontslag)regels gelden voor welke bestuurder?, Ondernemingsrecht 2019, nr. 62; S.J. Sterk, De arbeidsovereenkomst van de bestuurder na een statutair ontslag: een lege huls met uitgeholde ontslagbescherming?, Maandblad voor Ondernemingsrecht 2017-8/9; T.A. Wilms, De positie van de tekortschietende bestuurder binnen het grondenstelsel van de Wet werk en zekerheid, Bedrijfsjuridische berichten 2017, nr. 21.

8 Vgl. Bennaars 2014: 'Het gaat in de eerste plaats om opzeggingen met toestemming van het UWV of de cao-commissie. Als de werknemer van oordeel is dat de toestemming ten onrechte is verleend, kan hij de kantonrechter verzoeken de arbeidsovereenkomst te herstellen (lid 1 sub a); de werknemer kan dus in feite in beroep tegen de beslissing van het UWV/de cao-commissie.' 
(art. 7:682 lid 3 onder a BW), ${ }^{9}$ als de aangevoerde opzeggingsgrond niet redelijk is. ${ }^{10}$ Een voorbeeld van toepassing van art. 7:682 lid 3 BW is Rb. Gelderland 16 oktober 2019, ECLI:NL:RBGEL:2019:4618 (verzoeker 1 en GJKLM BV/Doors, Covers \& More BV, B\&S Harderwijk Beheer BV en (naam) Beheer BV). ${ }^{11}$ Verzoeker 1 was een van de bestuurders van Doors, Covers \& More BV ('DCM BV'). DCM BV hield zich bezig met het produceren van kunststofdeuren voor koelvitrines in supermarkten. Verzoeker 1 hield 2\% van de aandelen in DCM BV, en hield via GJKLM BV nog eens 5\% van de aandelen in DCM BV. De overige aandelen in DCM BV werden gehouden door B\&S Harderwijk Beheer BV (waarvan Beheer BV vrijwel alle aandelen hield). DCM BV heeft grote investeringen gedaan om een volledig geautomatiseerde fabriek voor het produceren van kunststofdeuren op te zetten. De algemene vergadering van DCM BV heeft verzoeker 1 op 14 maart 2019 ontslagen. DCM BV heeft dit ontslag bij brief van 27 maart 2019 bevestigd en de (resterende) arbeidsovereenkomst met verzoeker 1 opgezegd. Als reden voor de beëindiging voerde DCM BV aan dat sprake was van een verschil van mening over het te voeren beleid, in die zin dat verzoeker 1 zich als commercieel directeur te weinig bezighield met het vergroten van de omzet. Verzoeker 1 heeft de rechtbank verzocht hem ten laste van DCM BV een billijke vergoeding toe te kennen van $€$ 1.827.000. De rechtbank overwoog dat de redenen voor opzegging die DCM BV had aangevoerd in de opsomming van art. 7:669 lid 3 BW het meest pasten bij de h-grond. Weliswaar had DCM BV daar later nog de d- en g-gronden aan toegevoegd (dat verzoeker 1 zijn tijd verkeerd gebruikte en niet aan de verwachtingen voldeed), maar dat vond de rechtbank ontoelaatbaar: $:^{12}$

'4.6. (...) Voor invoering van de Wet Werk en Zekerheid kon een statutair bestuurder middels een procedure ter zake het kennelijk [onredelijk] ontslag opkomen tegen het ontslag en een vergoeding vorderen. In een dergelijke procedure werden door de werkgever nadien aangevoerde gronden niet meegenomen. Er is geen reden daarover nu anders te oordelen. Een statutair bestuurder die, zonder preventieve toetsing, wordt ontslagen, dient te weten waartegen hij zich moet verweren. Het toestaan van een dergelijke uitbreiding na het gegeven ontslag is dan ook in strijd met een goede procesorde. Reeds om die reden kan het beroep van DCM op een verstoorde arbeidsrelatie (de g-grond) en/of disfunctioneren (de d-grond) niet slagen.'

9 Vgl. E.S. de Bock, De statutair bestuurder onder Werk en zekerheid, ArbeidsRecht 2014, nr. 53: 'Weliswaar kan een bestuurder van een BV of NV niet om herstel van de arbeidsverhouding verzoeken gegeven art. 2:134 en 2:244 BW, wel is het mogelijk op grond van art. 7:682 lid 3 BW een verzoek in te dienen voor een billijke vergoeding niet alleen als sprake is van ernstig verwijtbaar handelen of nalaten van de werkgever, maar ook als sprake is van strijdigheid met art. 7:669 BW.'

10 Vgl. Bennaars 2014; Bennaars 2019; Wilms 2017.

11 Vgl. ook Rb. Rotterdam 18 februari 2019, ECLI:NL:RBROT:2019:2172 (verzoeker/ Drogisterij.Net BV).

12 Vgl. Bennaars 2019. 
Vervolgens overwoog de rechtbank dat de manier waarop DCM BV de h-grond had onderbouwd eigenlijk neerkwam op een onderbouwing die paste bij de (te laat aangevoerde) d-grond. Daarom was geen sprake van 'een voldragen h-grond': 'De gestelde h-grond levert dan ook geen redelijke grond op die de opzegging kan dragen.' De rechtbank kende een billijke vergoeding toe van $€ 50.000$ : 'Al met al komt toekenning van een billijke vergoeding ad $€ 50.000,00$ bruto, globaal overeenkomend met ongeveer zes maandsalarissen, de rechtbank redelijk voor.'

\subsection{Art. 7:681 BW}

Art. 7:681 BW geeft de rechter de mogelijkheid in een aantal gevallen de opzegging door een werkgever van de arbeidsovereenkomst te vernietigen, of aan de werknemer ten laste van de werkgever een billijke vergoeding toe te kennen. Een van die gevallen (art. 7:681 lid onder b BW) is de situatie waarin de werkgever de arbeidsovereenkomst heeft opgezegd in strijd met de opzegverboden van art. 7:670 BW (of in strijd met vergelijkbare opzegverboden in een ander wettelijk voorschrift'). ${ }^{13}$ Art. 7:670 BW bevat een aantal opzegverboden. Deze opzegverboden zijn (verkort weergegeven): opzegging tijdens ziekte gedurende een periode van twee jaar (lid 1), opzegging gedurende zwangerschap (lid 2), opzegging gedurende dienstplicht (lid 3), opzegging van een werknemer die lid is van de ondernemingsraad (lid 4), opzegging wegens lidmaatschap van een vakbond (lid 5), opzegging wegens het als lid bijwonen van vergaderingen van de Eerste Kamer (lid 6), opzegging wegens het geldend maken van geboorteverlof (lid 7), opzegging wegens overgang van een onderneming (lid 8), opzegging wegens het niet instemmen met het werken op zondag (lid 9), en opzegging van een werknemer die geplaatst is op een kandidatenlijst van een ondernemingsraad (lid 10). Het gaat in deze situaties niet om herstel van de arbeidsovereenkomst, maar om vernietiging van de opzegging. Dat betekent dat de rechter bij opzegging van de arbeidsovereenkomst met een bestuurder van een vereniging, een naamloze vennootschap of een besloten vennootschap in strijd met een opzegverbod die opzegging zowel kan vernietigen (deze situaties vallen buiten het bereik van art. 2:37 lid 6 tweede volzin BW, art. 2:134 lid 3 BW en art. 2:244 lid 3 BW) als aan de bestuurder een billijke vergoeding kan toekennen die de rechtspersoon moet betalen.

\section{De stichting: nu nog een uitzondering}

Voor de stichting bepaalt art. 2:286 lid 3 BW dat de statuten van een stichting 'de wijze van benoeming en ontslag der bestuurders' moeten regelen. De statuten kunnen bijvoorbeeld inhouden dat de stichting slechts één orgaan heeft, het bestuur, dat zijn eigen leden benoemt en ontslaat (coöptatie). De statuten kunnen ook inhouden dat de stichting twee organen heeft, een raad van toezicht en een bestuur, waarbij de raad van toezicht zijn eigen leden benoemt en ontslaat (coöptatie), en de bevoegdheid heeft de bestuurders te benoemen en ontslaan. In de regeling van de stichting in Boek 2 BW is niet opgenomen dat de rechter niet 
kan overgaan tot het uitspreken van een veroordeling tot herstel van de arbeidsovereenkomst tussen de stichting en een stichtingsbestuurder. Hiermee wijkt de regeling van de stichting af van de regeling van de andere rechtspersonen in Boek 2 BW. Dat heeft als belangrijke consequentie dat het arbeidsrechtelijk ontslagrecht volledig van toepassing is op een stichtingsbestuurder. Wanneer het orgaan van een stichting dat bevoegd is de stichtingsbestuurders te ontslaan, overgaat tot ontslag van een bestuurder en vervolgens de (resterende) arbeidsovereenkomst met de bestuurder wil beëindigen, is de stichting dus verplicht hetzij de route van art. 7:669 lid 3 onder a of b BW te volgen (opzegging na toestemming te hebben gekregen van het UWV), hetzij de route van art. 7:669 lid 3 onder c tot en met i BW te volgen (ontbinding door de kantonrechter). ${ }^{14}$ Meestal zal, gelet op de in art. 7:669 lid 3 onder c tot en met i BW geformuleerde beëindigingsgronden, ontbinding van de arbeidsovereenkomst door de kantonrechter de voor de hand liggende weg zijn.

Voor de volledigheid: art. 2:298 BW bevat nog een andere ontslagmogelijkheid van een stichtingsbestuurder. Lid 1 van dit artikel bepaalt dat de rechtbank een stichtingsbestuurder kan ontslaan die 'iets doet of nalaat in strijd met de bepalingen van de wet of van de statuten, dan wel zich schuldig maakt aan wanbeheer', en wel op verzoek van het Openbaar Ministerie of iedere belanghebbende. ${ }^{15}$

Een voorbeeld van ontslag van een stichtingsbestuurder gevolgd door een verzoek tot ontbinding van de (resterende) arbeidsovereenkomst is Rb. Gelderland 6 november 2017, ECLI:NL:RBGEL:2017:5917, JAR 2017/298 (Stichting De Passerel/verweerder).

Stichting De Passerel was een zorginstelling die werkzaam was in Apeldoorn, Epe en Voorst. Stichting De Passerel had een raad van toezicht die uit zes personen bestond en een bestuur dat uit één persoon bestond (verweerder). De bestuurder van Stichting De Passerel was sinds 1981 werkzaam bij Stichting De Passerel, was bestuurder geworden en had (toen hij 62 jaar was) aangegeven dat hij zijn werkzaamheden vóór het bereiken van de pensioengerechtigde leeftijd wilde beëindigen. Zijn vertrek zou dan kunnen samenvallen met een wijziging van de organisatiestructuur van Stichting De Passerel. De raad van toezicht en de bestuurder zijn hierover in gesprek gegaan. Deze gesprekken zijn vastgelopen. De reden daarvoor was dat de Wet normering topinkomens een beperking inhield van de hoogte van een eventuele beëindigingsvergoeding die Stichting De Passerel aan de bestuurder zou mogen betalen. De raad van toezicht heeft de bestuurder per 1 oktober 2017 ontslagen. Stichting De Passerel heeft de kantonrechter verzocht de (resterende) arbeidsovereenkomst met de bestuurder te ontbinden. Stichting De Passerel baseerde dit verzoek op de g- en/of h-grond van art. 7:669 lid 3 BW. De kanton-

14 Vgl. Rb. Noord-Nederland 30 mei 2018, ECLI:NL:RBNNE:2018:2031, JAR 2018/156, JOR 2018/238 (Stichting Nordwin College/verweerder).

15 Vgl. HR 12 oktober 2018, ECLI:NL:HR:2018:1900, JOR 2018/296 (verzoeker/Stichting ANV Fondsen). 
rechter heeft het ontbindingsverzoek afgewezen. De kantonrechter overwoog onder meer:

'4.10 (...) dat de door de Passerel aangevoerde verstoring in de arbeidsverhouding voornamelijk is ontstaan door de opstelling van de Passerel na het moment dat partijen moeten concluderen dat geen overeenstemming bereikt kon worden over de vergoeding. $\mathrm{Nu}$ het een korte periode van verstoring betreft en (verweerder) daarin geen belemmering ziet voor hervatting van zijn werkzaamheden, mag van De Passerel - zeker in het licht van de zeer lange en ook door De Passerel gewaardeerde staat van dienst van (verweerder) - worden verlangd dat zij zich inzet voor herstel van het vertrouwen. (...).'

De voorgestelde Wet bestuur en toezicht rechtspersonen wijzigt het voorgaande. De tweede nota van wijziging trekt de ontslagpositie van stichtingsbestuurders gelijk aan de ontslagpositie van bestuurders van verenigingen, naamloze vennootschappen en besloten vennootschappen door te bepalen: ${ }^{16}$

'Na artikel 298 wordt een artikel toegevoegd, luidende:

Artikel 298a

1 Een veroordeling tot herstel van de arbeidsovereenkomst tussen de stichting en de bestuurder kan door de rechter niet worden uitgesproken.

2 Het in het voorgaande lid bepaalde is van overeenkomstige toepassing op commissarissen.'

Opvallend is hier ook het tweede lid dat de regeling van lid 1 van overeenkomstige toepassing verklaart op commissarissen, die (veelal) niet werkzaam zijn op basis van een arbeidsovereenkomst maar op basis van een overeenkomst van opdracht.

Ten slotte: de voorgestelde Wet bestuur en toezicht rechtspersonen wijzigt ook art. 2:298 BW. De eerste nota van wijziging maakt ontslag van een stichtingsbestuurder via art. 2:298 BW gemakkelijker:

'Artikel 298 komt te luiden:

Artikel 298

1 Een bestuurder kan op verzoek van een belanghebbende of van het openbaar ministerie door de rechtbank worden ontslagen wegens verwaarlozing van zijn taak, wegens andere gewichtige redenen, wegens ingrijpende wijziging van omstandigheden op grond waarvan het voortduren van zijn bestuurderschap in redelijkheid niet kan worden geduld (...).' 


\section{Conclusie}

Het doel van de voorgestelde Wet bestuur en toezicht rechtspersonen is uniformering en verduidelijking van de regelingen in Boek 2 BW over bestuurders en commissarissen. Wat betreft de rechtspositie van bestuurders van stichtingen slaagt de wet daarin, door de beëindiging van de arbeidsovereenkomst met een bestuurder van een stichting na ontslag op één lijn te brengen met de al bestaande regelingen voor bestuurders van verenigingen, naamloze vennootschappen en besloten vennootschappen. Wat betreft de rechtspositie van commissarissen van een stichting leidt art. 2:298a lid 2 BW juist tot een opvallende anomalie, waarvoor de redengeving in de (oorspronkelijke) memorie van toelichting enkel luidt:

'De overwegingen die ten grondslag liggen aan de gegeven mogelijkheid tot ontslag van een stichtingsbestuurder, gelden eveneens ten aanzien van een commissaris. De regeling wordt daarom van overeenkomstige toepassing verklaard op commissarissen van een stichting.' 